\title{
Genetic Variation of 6-Phosphogluconate Dehydrogenase, Isocitrate Dehydrogenase, and Glutamic-oxaloacetic Transaminase in the Liver of Japanese Eel*1
}

\author{
Nobuhiko TANIGUCHI ${ }^{* 2}$ and Ken-ichi NumaCHI ${ }^{* 3}$
}

(Received June 2, 1978)

\begin{abstract}
Two groups of the Japanese eel, Anguilla japonica, one from Fuchien, China, and the other from Kochi, were analyzed for electrophoretic variation of enzymes in liver. Distinct genetic variations were found in 6-phosphogluconate dehydrogenase (6-PGD), isocitrate dehydrogenase (ICD), and glutamic-oxaloacetic transaminase (GOT). Ten different phenotypes detected in 6PGD were accounted for by assuming five alleles at a locus encoding this enzyme. Two of the five alleles were detected in relatively high frequencies in both the samples. Eight phenotypes of ICD were postulated to result from four alleles at a locus. IICd allele was most common in the two samples. The most cathodal system of the three or four different ones of GOT exhibited three phenotypes, which were presumed to be controlled by two alleles at a locus termed Got-III. Statistically significant differences in the allele frequencies could not be observed between the two samples except those of $I c d^{\mathrm{b}}$, which were detected in low frequencies $(0.073$ and 0.120$)$ in the samples.
\end{abstract}

The Japanese eel, Anguilla japonica, is widely distributed in the freshwaters of the east Asia. The location and number of spawning ground of, and population structure in this species have as yet been unclear. Usefulness of biochemical traits was exemplified for the study of Atlanitic eel populations by many authors. ${ }^{1-8)}$ SiCK et al. ${ }^{1,21}$ found genetic variation of hemoglobin in the Atlantic eels, supporting the SCHMIDT's theory ${ }^{9,101}$ that eels in the Atlantic Ocean constitute two separate species, the American eel, Anguilla rostrata and the European eel, $A$. anguilla. Biochemical studies on esterase, transferrin, and hemoglobin by Pantelouris et $a l^{5,6)}$ also supported the SchmidT's theory, and suggested a differentiation of subpopulations within the respective species of Atlantic eel. On the basis of allelic frequencies in esterase, sorbitol dehydrogenase, phosphohexose isomerase, and malate dehydrogenase, WIILIAMs et al ${ }^{87}$ also found population differences within $A$. rostrata.

The present paper describes the results of analysis on genetic variations in 6-phosphogluconate dehydrogenase, isocitrate dehydrogenase, and glutamic-oxaloacetic transaminase of the liver of Japanese eel sampled from Japan and China.

\section{Materials and Methods}

\section{Materials}

The samples of Japan contained 210 specimens, ranging between $184-353 \mathrm{~mm}$ in total length captured in 1976 from the River Shimanto, Kochi Prefecture, and 87 specimens (total length unknown) collected from a fishmarket in Kochi city in 1976. The samples of China included 117 specimens, ranging $121-350 \mathrm{~mm}$, imported from Fuchien, China, through the Eel Culture Institute of Yoshida, Shizuoka Prefecture, Japan, in April, 1976.

\section{Methods}

All the specimens were kept frozen at $-20^{\circ} \mathrm{C}$ until use. Liver was hackled by small scissors in approximately one-third volume of a solution containing $0.005 \mathrm{M} \mathrm{MgCl}_{2}$ and $0.005 \mathrm{M} \mathrm{NaCN}$. The exudation of liver was applied to gels with small pieces of filter paper. Horizontal starch-gel electrophoresis was performed with a current of $4 \mathrm{~mA}$ per $1 \mathrm{~cm}^{2}$ of cross section. Starch-gel was prepared as a $12 \%$ gel in the citric acid-aminopropylmorpholin buffer system described by CLAYTON et al. ${ }^{11} \quad$ The staining recipes of three en-

*1 Supported in part by the grant for co-operative study from Ocean Research Institute, The University of Tokyo.

*2 Department of Cultural Fisheries, Faculty of Agriculture, Kochi University, Nankoku, Kochi 783 (谷口 順度: 高知大学曟学部载培漁業学科).

*3 Otsuchi Marine Laboratory, Ocean Research Institute, The University of Tokyo, Otsuchi, Iwate, 028-11 (沼知健一：東京大学海洋研究所大䊚臨海研究七ンター). 
zymes were as follows:

(1) 6-phosphogluconate dehydrogenase (6PGD; EC 1.1.1.44). Isozyme was identified with a solution containing $20 \mathrm{~m} l$ of $0.1 \mathrm{M}$ tris buffer (pH 8.0), $10 \mathrm{mg}$ 6-phosphogluconate, $6 \mathrm{mg}$ NADP, ${ }^{* 1} 1 \mathrm{mg} \mathrm{PMS}, *^{2} 2 \mathrm{mg} \mathrm{NBT},{ }^{*} 0.2 \mathrm{ml}$ of $1 \mathrm{M} \mathrm{MgCl}_{2}$.

(2) Isocitrate dehydrogenase (ICD; EC 1. 1. 1. 42). ICD was detected with a solution containing $20 \mathrm{ml}$ of $0.1 \mathrm{M}$ tris buffer $(\mathrm{pH} 8.0), 8 \mathrm{mg}$ isocitrate, $6 \mathrm{mg}$ NADP, $1 \mathrm{mg}$ PMS, $2 \mathrm{mg} \mathrm{NBT}$, and $0.2 \mathrm{ml}$ of $1 \mathrm{M} \mathrm{MgCl}_{2}$.

(3) Glutamic-oxaloacetic transaminase (GOT; EC 2.6.1. 1.) GOT was identified with a solution at $\mathrm{pH} 7.0$ consisting $25 \mathrm{mg} \alpha$-ketoglutaric acid, $45 \mathrm{mg}$ L-aspartic acid, $20 \mathrm{mg}$ EDTA, and $0.6 \mathrm{~g} \mathrm{NaH}_{2} \mathrm{PO}_{4}$, per $20 \mathrm{ml}$.

\section{Results and Discussion}

Electrophoretic variations of enzymes were found of 6-PGD, ICD and GOT, each presumably representing different genotypes formed by the alleles at three distinct loci encoding respective enzymes.

\section{6-PGD}

The electrophoreic patterns of 6-PGD in $A$. japonica is shown in Fig. 1. Each individual had one or three major bands without exception, so that the individuals with a single band were presumed to be homozygotes and the individuals with 3 bands to be heterozygotes. Three banding mode of heterozygotes indicates that 6-PGD of A. japonica is a dimer with subunits coded by a single locus, as has been demonstrated for cyprinid fishes $^{12 \prime}$ and other animals. ${ }^{131}$ The five different homodimeric bands found in the 6-PGD zymograms suggest the existance of five codominant alleles at the locus. Thus, 15 phenotypes are presumed to be formed by segregation of five alleles at the Pgd locus. The frequencies of phenotypes in each group were shown in Table 1. Types $B$ and $B C$ were most frequent, types $A B, A C, B D$, $\mathrm{BE}, \mathrm{C}, \mathrm{CD}, \mathrm{CE}$, and $\mathrm{D}$ were in relatively low frequencies, and types $\mathrm{A}, \mathrm{AD}, \mathrm{AE}, \mathrm{DE}$, and $\mathrm{E}$ were absent in the samples. The allelic frequency was high in $P g d^{\mathrm{b}}$ and $P g d^{\mathrm{c}}$ and low in $P g d^{\mathrm{a}}, \boldsymbol{P g} d^{\mathrm{d}}$, and $P g d^{\circ}$. Phenotypic frequency of each sample was consistent with that expected by the genetic interpretation as shown in Chi-square value in Table 1.

\section{ICD}

Eight phenotypes of ICD, as shown in Fig. 1, have been detected in both the two samples. These

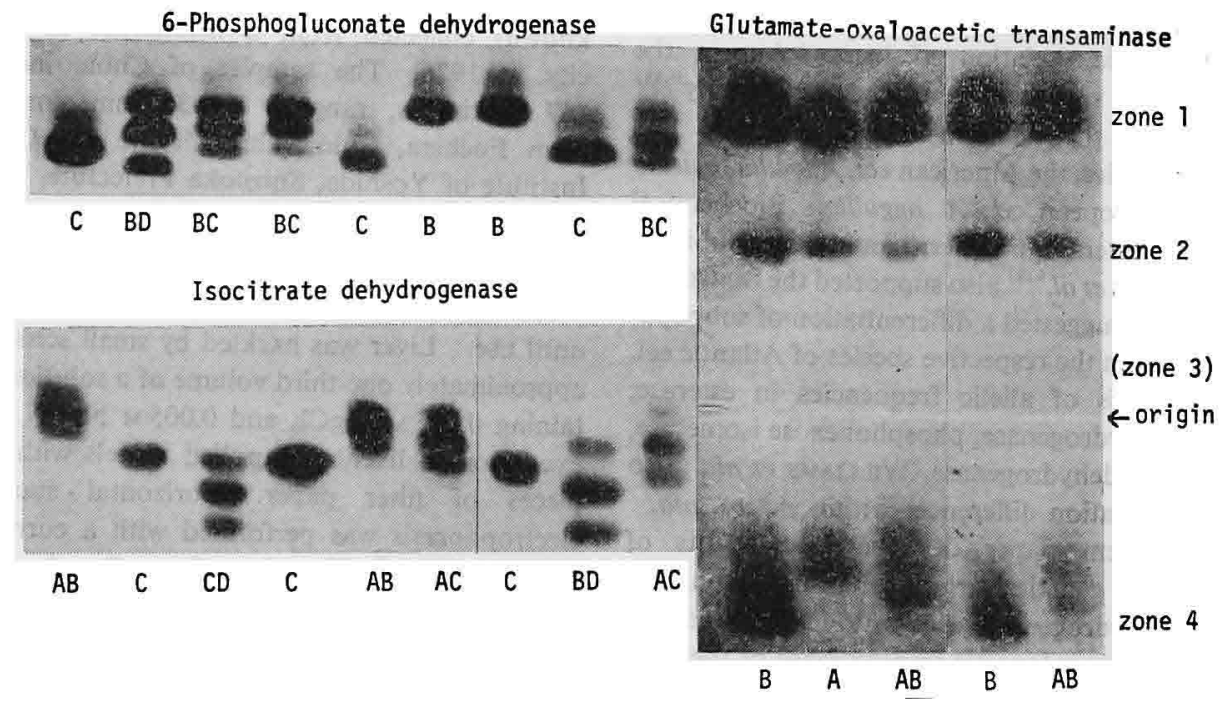

Fig. 1. Examples of 6-PGD, ICD, and GOT zymograms of Anguilla japonica. The 3rd zone in the GOT zymogram was not found in liver exudation, but was found in serum or whole elver homogenate.

*1 nicotinamide adenine dinucleotide phosphate

*2 phenazine methosulfate

*3 nitro blue tetrazolium 


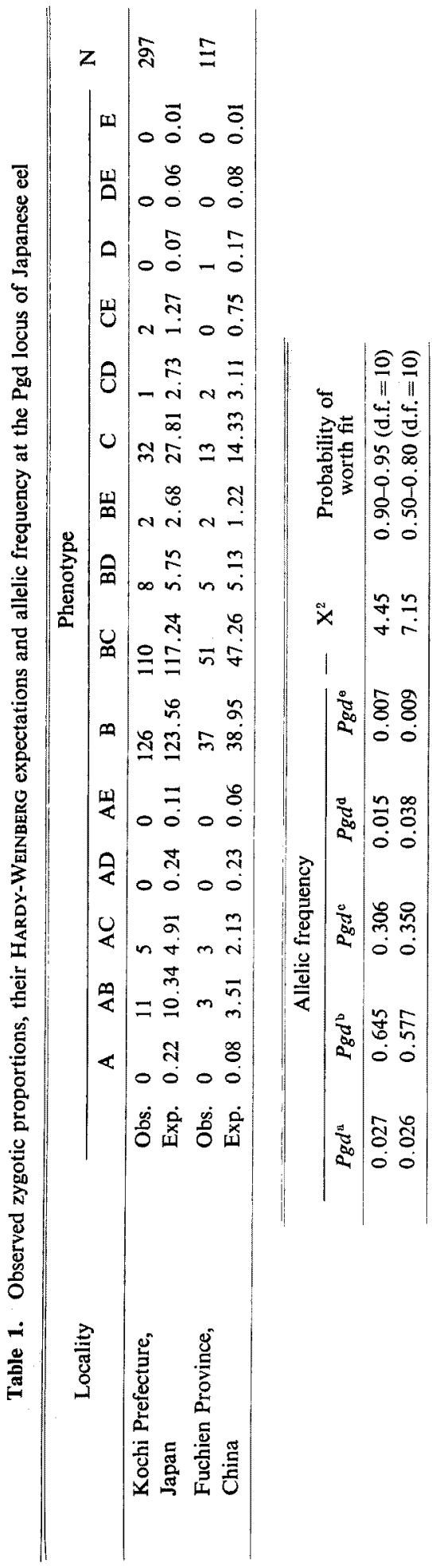

patterns suggest that ICD phenotypes are controlled by four codominant alleles. In Japanese eel, types $\mathrm{AC}, \mathrm{BC}$, and $\mathrm{C}$ were common, types $\mathrm{A}$, $A B, B, B D$, and $C D$ were in relatively low frequencies, and types $\mathrm{AD}$ and $\mathrm{D}$ were absent (Table 2). The allelic frequency was high in $I c d$, low in the other alleles. The zygotic proportion of ICD of each sample was consistent with expected proportion calculated from HARDY-WEINBERG law as shown in Chi-square value in Table 2.

GOT

Pantelouris et al..$^{71}$ showed that the GOT isozyme of Anguilla anguilla consists of four zones, and the heavy variable zones 1 and 2 are controlled by 4 alleles of each locus. In the Japanese eel, presumed homozygous individuals exibited equal spaced 3 bands (zones 1-3) of GOT activity in the anode side of the gel, while heterozygous individuals exibited 6 bands (the 1st zone consists of 3 bands, the 2 nd zone 2 bands, and the 3 rd zone single band). The 3rd zone was not found in liver, but appeared only in serum or whole elver homogenate. These banding modes of homozygous and heterozygous individuals are consistent with a dimeric isozyme structure of GOT as has been demonstrated for cyprinid fish ${ }^{14}$ and other animals. ${ }^{13)}$ Judging from these banding mode, the 2nd zone is considered to be heterodimer of two different allelic products.

As to the 4th zone which migrated towards the cathode, presumed heterozygous individuals had 3 bands. Therefore, it was concluded that GOT isozyme is under the control of 3 different loci, Got-I (directly controling the 1st zone), Got-II (the 3 rd zone), and Got-III (the 4th zone). The incidence of the variations of Got-I and Got-II isozyme systems was found in very low frequencies for a genetic analysis. The Got-III was classified into 3 types $A, A B$, and $B$ as shown in Fig. 1 without exception. Thus, the Got-III isozyme was considered to be controlled by 2 alleles at a single locus. The phenotypic composition and HARDYWEIBERG proportion of each sample were shown in Table 3. The genetic model of Got-III was ascertained by the Chi-square values for the test of goodness-of-fit of phenotypic composition and their HARDY-WEINBERG proportion (Table 3).

Heterogeneity Tests among the Samples Collected from Japan and China

Between the two samples collected from Japan and China, statistically significant differences in the allelic frequencies could not be observed, 
Table 2. Observed zygotic proportions, their HARDY-WeINBERG expectations and allelic frequency at the $I c d$ locus of Japanese eel

\begin{tabular}{|c|c|c|c|c|c|c|c|c|c|c|c|c|c|}
\hline \multirow{2}{*}{\multicolumn{2}{|c|}{ Locality }} & \multicolumn{12}{|c|}{ Phenotype } \\
\hline & & & $\mathbf{A}$ & $\mathrm{AB}$ & AC & $\mathrm{AD}$ & B & BC & $\mathrm{BD}$ & $\mathrm{C}$ & $\mathrm{CD}$ & D & $\mathbf{N}$ \\
\hline \multirow{4}{*}{\multicolumn{2}{|c|}{$\begin{array}{l}\text { Kochi Prefecture, } \\
\text { Japan } \\
\text { Fuchien Province, } \\
\text { China }\end{array}$}} & Obs. & 13 & 13 & 80 & 0 & 6 & \multirow{2}{*}{$\begin{array}{l}44 \\
47.74\end{array}$} & 2 & 136 & 2 & 0 & \multirow[t]{2}{*}{296} \\
\hline & & Exp. & 11.96 & 14.28 & 79.96 & 0.83 & 4.26 & & 40.50 & 133.67 & 2.78 & 0.01 & \\
\hline & & Obs. & 6 & 2 & 29 & 0 & 2 & \multirow{2}{*}{$\begin{array}{l}11 \\
12.56\end{array}$} & 0 & 65 & 2 & $\mathbf{0}$ & \multirow[t]{2}{*}{117} \\
\hline & & Exp. & 3.96 & 3.14 & 31.65 & 0.39 & 0.62 & & 60.15 & 63.21 & 1.55 & 0.01 & \\
\hline \multicolumn{7}{|c|}{ Allelic frequency } & \multirow{2}{*}{$\mathrm{X}^{2}$} & \multirow{2}{*}{\multicolumn{4}{|c|}{$\begin{array}{l}\text { Probability of } \\
\text { worth fit }\end{array}$}} & & \\
\hline \multirow{3}{*}{ 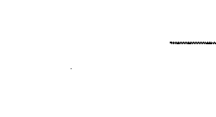 } & $I c d^{a}$ & \multicolumn{2}{|c|}{$I c d^{b}$} & $I c d^{\mathfrak{e}}$ & \multicolumn{2}{|r|}{$I c d^{\mathrm{d}}$} & & & & & & & \\
\hline & 0.201 & \multicolumn{2}{|c|}{0.120} & 0.672 & \multicolumn{2}{|c|}{0.007} & 6.80 & \multicolumn{4}{|c|}{$0.20-0.50(\mathrm{~d} . \mathrm{f} .=6)$} & & \\
\hline & 0.184 & 0.0 & & 0.735 & & .009 & 5.69 & \multicolumn{4}{|c|}{$0.20-0.50($ d.f. $=6)$} & & \\
\hline
\end{tabular}

Table 3. Observed zygotic proportions, their HARDY-WEInBERG expectations and allelic frequency at the Got-III locus of Japanese eel

\begin{tabular}{|c|c|c|c|c|c|c|c|c|}
\hline \multirow{2}{*}{ Locality } & \multicolumn{4}{|c|}{ Phenotype } & \multirow{2}{*}{$\mathbf{N}$} & \multirow{2}{*}{$\begin{array}{c}\text { Frequency of } \\
\text { Got-III }^{\mathrm{a}}\end{array}$} & \multirow{2}{*}{$\mathrm{X}^{2}$} & \multirow{2}{*}{$\begin{array}{c}\text { Probability of } \\
\text { worth fit }\end{array}$} \\
\hline & & A & $\mathrm{AB}$ & B & & & & \\
\hline Kochi Prefecture, & Obs. & 2 & 53 & 242 & 297 & 0.096 & 0.24 & $0.50-0.80(\mathrm{~d} . \mathrm{f} .=1)$ \\
\hline Japan & Exp. & 2.74 & 51.55 & 242.71 & & & & \\
\hline Fuchien Province, & Obs. & 3 & 22 & 92 & 117 & 0.120 & 1.35 & $0.20-0.50($ d.f. $=1)$ \\
\hline China & Exp. & 1.68 & 24.71 & 90.60 & & & & \\
\hline
\end{tabular}

except those of $I c d^{\mathrm{b}}\left(\mathrm{X}^{2}=3.85,0.05>\mathrm{P}>0.02\right)$ which was in low frequencies $(0.073$ and 0.120$)$ in the samples. The differences are statisticaly nonsignificant in allelic frequency of $P g d^{\mathrm{b}}\left(\mathrm{X}^{2}=3.31\right.$, $0.10>\mathrm{P}>0.05$ ), and in allelic frequency of $I c d^{\mathrm{c}}$ $\left(\mathrm{X}^{2}=3.11,0.10>\mathrm{P}>0.05\right)$. Though the differences were not significant, these suggest the possibility of subpopulational differentiation in the Japanese eel. It is also undeniable that such degree of differences observed here arises anew within the same generation from early uniformity as has been discussed by Williams et $a l^{8}{ }^{8}$ Although the spawning area of the Japanese eel may be narrow ${ }^{15}$ it is not exactly proved that local populations distributing in the freshwaters of eastern part of Asia are derived from a single population of the same spawning area at the same season. These investigations of eel subpopulations, therefore, must be continued further to clear up the components of subpopulations of the Japanese eel.

\section{Acknowledgement}

The authors wish to thank Dr. Akira OcHIAl, Professor of Kochi University, for his encouragement, Dr. Kazuo Funino, Professor of Kitasato University, and Dr. Sadao ShImeno, Associate Professor of Kochi University, who kindly read the manuscript and gave invaluable suggestions. The authors are also indebted to $\mathrm{Mr}$ Kazutami Nishro of the Eel Culture Institute of Yoshida, Shizuoka, and Mr. Takeru YAMAZAKı of Nakamura city, Kochi Pref, for their furnishing the samples of eel from China and the River Shimanto, respectively.

\section{References}

1) K. Sick, M. WestergaArd, and O. FrydengerG: Nature, 193, 1001-1002 (1962).

2) K. Sick, E. BAHN, O. Frydentberg, J. T. NIELSEN, and D. von WetTSTEIN: Nature, 214, 11411142 (1967).

3) E. M. Pantelouris and R. H. Payne: Genet. Res., 11, 319-325 (1968).

4) E. M. Pantelouris, A. Arnason, and F. W. Tesch: Genet. Res., 16, 277-284 (1970).

5) E. M. Pantelouris, A. Arnason, and F. W, TeSCH: Mar. Biol., 9, 242-249 (1971).

6) E. M. Pantelouris, A. Arnason, and R. Bumpus: J. Exp. Mar. Biol. Ecol., 22, 113-121 (1976).

7) E. M. Pantelouris: J. Exp. Mar. Biol., 22, 123130 (1976).

8) G. C. Williams, R. K. KoehN, and J. B. Mitton: Evolution, 27, 192-204 (1973).

9) J. Schmidt: Phil. Trans. R. Soc. (B), 211, 179208 (1922). 
10) J. SchmidT: Smithsonian Rept, in 1924, 279-316.

11) J. W. Clayton and D. N. Tretiak: J. Fish. Res. Bd. Canada, 29, 1169-1172 (1972).

12) J. Klose, U. Wolf, H. Hitzeroth, H. Ritter, and S. Orno: Humangenetik, 7, 245-250 (1969).

13) D. W. Darnall, and I. M. Klots: Arch. Bio- chem. Biophys., 149, 1-14 (1972).

14) J. SChmidTKe and W. Engel: Experientia, 28, 976-978 (1972).

15) I. Matsur: Eel biology; A biological study (In Japanese), Koseisha-Koseikaku, Tokyo, 1972, pp. 76-95. 